\title{
Research on the Education Path of Red Culture Integrating into the Core Values of Chinese Socialism in Colleges and Universities
}

\author{
Yue Chen \\ College of Mechanical and Electrical Engineering, Southwest Petroleum University, Chengdu, China \\ Email: 1334100761@qq.com
}

How to cite this paper: Chen, Y. (2020) Research on the Education Path of Red Culture Integrating into the Core Values of Chinese Socialism in Colleges and Universities. Open Journal of Social Sciences, 8, 295-302.

https://doi.org/10.4236/jss.2020.81022

Received: December 29, 2019

Accepted: January 14, 2020

Published: January 17, 2020

Copyright $\odot 2020$ by author(s) and Scientific Research Publishing Inc. This work is licensed under the Creative Commons Attribution International License (CC BY 4.0).

http://creativecommons.org/licenses/by/4.0/

\begin{abstract}
In recent years, the state has paid more and more attention to the development and utilization of red cultural resources. Colleges and universities are also seeking to deepen the carrier of socialist core values education, trying to integrate red culture into the socialist core values education in colleges and universities. This paper mainly discusses the possibility and necessity of integrating red culture into the socialist core values of colleges and universities through theoretical analysis and comprehensive methods, starting from the reality of colleges and universities at present, and using the problem analysis method, starting from three aspects of resource distribution, content transmission and path development, analyzes the problems existing in the actual process, and explores the effective way of red culture into the socialist core values education in colleges and universities.
\end{abstract}

\section{Keywords}

Red Culture, The Core Values of Chinese Socialism, Colleges and Universities

\section{Introduction}

At present, with the increasingly frequent exchanges between countries, the collision between different cultures is becoming more and more obvious, and the development of culture shows a trend of diversification and complexity. Among the numerous cultural choices, how to adhere to the national spirit with Marxism as the guide, patriotism as the core and the spirit of the times with reform and innovation as the support has become the top priority in the construction of a harmonious campus culture. It is very important for college students to establish correct values, to strengthen the ideals and beliefs of striving for the socialist 
cause construction, and to cultivate and practice the socialist core values of college students to seek the education path of integrating red culture into the socialist core values of colleges and universities.

\section{The Possibility and Necessity of Integrating Red Culture into the Core Values of Chinese Socialism of Colleges and Universities}

Red culture is the source of socialist core values and the important support and carrier of campus culture construction. As an advanced culture in China, red culture has something in common with the core values of socialism in the new era from the national, social and personal levels. Both of them have the possibility and necessity of combination.

\subsection{The Possibility of Integrating Red Culture into the Core Values of Chinese Socialism of Colleges and Universities}

From the national level, red culture includes the contents of "prosperity, democracy, civilization and harmony". Red culture itself is formed by the Communist Party of China in the process of pursuing national independence and national prosperity, which contains the contents of "democracy" and "prosperity and strength". A history of the development of the Communist Party of China is the history that the Communist Party of China led the Chinese people to explore and strive for the road of saving the country and the people, enriching the country and strengthening the country. From the social level, red culture contains the content of "freedom, equality, justice and rule of law". Marxism is a theory about the complete liberation of the proletariat and all mankind in the world. The Communist Party of China is a party guided by Marxism. It always takes the realization of the great rejuvenation of the Chinese nation and serving the people wholeheartedly as its mission and purpose, and leads the people to carry out the arduous struggle of pushing over the "three mountains". From the personal level, red culture includes "Patriotism, dedication, integrity and friendliness". Red culture is not only reflected in the grand level of the country and society, but also in the value pursuit of the individual. During the period of revolution, construction and reform, a group of touching stories full of patriotism emerged. At the same time, the long march road, military and civil sentiment also reflect the value pursuit of dedication and friendliness.

\subsection{The Necessity of Integrating Red Culture into the Core Values of Chinese Socialism of Colleges and Universities}

Xi Jinping pointed out: "whether we can do well in ideological work is closely related to the future and destiny of the party. It is related to the long-term stability and national cohesion and centripetal force of our country". It also pointed out in the 19th National Congress of CPC reports: "firmly grasp the leadership of ideological work." With the rise of the Internet, the struggle in the field of ideology in the world is increasingly fierce. Whether we can firmly grasp the 
party's dominant power and voice in the field of ideology is related to the ruling position of the party, the people's ideals, beliefs and value pursuit, and the realization of the Chinese dream. Red culture is the concentrated embodiment of the party's ideology. Red culture was born in the revolutionary era. Its emergence is to take the people as the center, adhere to the belief of Marxism and the lofty ideal of communism, and help the Chinese people get liberation. In the new era, to further inherit and develop the red culture is to safeguard the ideology of the proletariat and strengthen the rational belief of the people. The core values of socialism reflect the essential requirements of socialist ideology, and focus on the expression of the road, theoretical system and system of socialism with Chinese characteristics from the value level. It can be seen that both red culture and socialist core values are to consolidate and strengthen the guiding position of Marxism in the ideological field, further strengthen the cultural self-confidence of college students, and do not provide a path for wrong ideas.

\section{The Main Problems in the Integration of Red Culture into the Education of Socialist Core Values in Colleges and Universities}

Red culture provides an effective way for colleges and universities to effectively spread the socialist core values, but in the actual operation process, due to the red culture and the subjective and objective factors in colleges and universities, there are some problems in the integration of red culture into the socialist core values education in colleges and universities, mainly in the following aspects.

\subsection{Imbalance of Resources: Uneven Distribution of Red Culture Leads to a Large Gap in the Integration of Colleges and Universities}

Red culture is produced and developed in a specific historical background, and because of China's wide region, there are regional differences in the distribution of red cultural resources. According to the four geographical regions of China, the north, northwest, South and Qinghai Tibet, the red revolutionary base areas are mainly concentrated in the South and northwest, with the most in the south [1]. Colleges and universities with rich red resources not only have a more convenient carrier of socialist core values, but also can get more attention from the state, local, school and other aspects, so that colleges and universities will be more active in investment, and teachers and students will be more involved. However, areas where red resources are relatively scarce, colleges and universities want to use red cultural resources for socialist core values education, the cost will be higher, and more human, material and energy will be spent, and the development and utilization of red culture in these schools will be relatively weak. In addition, different regions and universities have different conditions, so there are great differences in the investment of education cost and the emphasis of education content, so that the effectiveness of integrating red culture into the socialist core values of universities is different. 


\subsection{Lack of Agreement in Content: Lack of Agreement in the Selection of Red Resources and the Education of Socialist Core Values}

Ideological and political theory classroom is an important channel for colleges and universities to spread red culture. If teachers want to make students firm cultural confidence and cultivate the firm belief of socialist core values through the explanation of red culture, they need to select more reasonable red resources. Some college teachers in the red culture into the classroom to carry out the socialist core values, there are improper selection of red resources to reduce the quality of the classroom, and even counterproductive situation. For example, the choice of red story is lack of representativeness and typicality, which makes it rigid and inflexible to integrate into the teaching of Ideological and political theory; the integration of red story into Ideological and political theory is lack of pertinence, which is not combined with the specific level of socialist core values; the integration of red story into Ideological and political theory is lack of value, so teachers are telling in order to enhance the attractiveness of the classroom The time service will focus on the love stories and anecdotes of some historical figures, diluting the theme of Ideological and political theory teaching.

In recent years, many colleges and universities have set up red culture education bases with red history museums, red memorial halls, red sites, etc. However, no matter in the choice of bases or the design of contents, red culture is more or more reflected in patriotism when carrying out the education of socialist core values, and the education of other levels of core values is not enough.

\subsection{Path Incongruity: Education Incongruity between Universities and Society, and within Universities}

Red cultural resources belong to social resources. If colleges and universities want to make good use of this resource to carry out socialist core values education, they must coordinate the relationship between society and schools. In recent years, more and more red cultural resources appear in front of the public in terms of red tourism, and the phenomenon of red cultural resources marketization is becoming more and more obvious. Market-oriented development has two sides. Moderate market-oriented development can provide economic basis for the protection of red resources, and make more people understand and accept red culture, which has a positive effect on the popularization and development of red culture. However, many local governments are still not in place in the excavation and development of red resources. The government only pays attention to the economic value brought by the red sites, has insufficient understanding of the educational function of the red resources, and fails to give full play to the connotation and value of the red resources, resulting in the phenomenon that the economic value conceals the educational value.

In terms of the internal environment of the school, there is still a lack of coordination among the institutions such as colleges and administrative departments. Different colleges have different emphasis on students' training and dif- 
ferent practical activities. At present, the enthusiasm of school of Marxism is high, and the enthusiasm of students to participate in related activities is also

high. However, the participation of other students is not enough, showing a unique state of school of Marxism, which is closely related to the attention degree between colleges. At the same time, the activities of red culture education carried out by the students' competent department and the activities of red culture education carried out by the ideological and political theory course often overlap. Each of them carries out their own activities without forming a joint force of education, which wastes resources and has poor effect.

\section{Countermeasures and Suggestions on the Integration of Red Culture into the Education of Socialist Core Values in Colleges and Universities}

In the face of the practical dilemma of red culture integrating into the socialist core values education in colleges and universities, colleges and universities can innovate red culture education, strengthen the construction of red position and adhere to red culture education from three dimensions of building platform, optimizing content and forming joint forces.

\subsection{Build a Platform: Build an Internet plus Red Culture Education Mode}

According to the 42nd statistical report on the development of China's Internet by China Internet Information Center (CNNIC), as of June 2018, the number of Internet users in China reached 802 million, and the Internet penetration rate was $57.7 \%$. With the further development of Internet, "Internet plus Red Culture" has become a new trend of integrating red culture into the socialist core values of colleges and universities. A survey shows that in the survey of "what kind of way do you want schools to carry out socialist core values education", all kinds of new media have become the most popular education platform for college students [2]. The Internet has made red resources break through the regional restrictions, so that students can have access to and understand red resources and red culture in different regions, and guide teachers and students to participate in the learning and innovation of red culture. At present, some colleges and universities have begun to use modern media technology to expand the traditional static display into dynamic display, and use Internet technology to show the classic historical events and character stories in the red culture in the form of graphics, sound and so on, so as to enhance the appeal and attraction of the red culture.

Red culture and value leading theme education website is an important carrier of network ideological and political education, and a direct platform for college students to obtain red culture information and exchange and discuss socialist core values. In the construction of the website, we should adhere to the guiding position of Marxism, firmly grasp the position consciousness, integrate the red culture into the content of the socialist core values, combine the explicit educa- 
tion with the implicit education, enrich the educational content and form of the website, and help students form a stable value psychological consciousness and structure.

\subsection{Optimizing Content: Digging Deep into the Relationship between Red Culture and Socialist Core Values}

The content is the soul of education. In order to integrate red culture into the core value education of socialism in colleges and universities, we must further improve and optimize the content of education, carefully comb the value factors contained in red culture, deepen the research on the value leading and value shaping functions of red culture, and find the fit between red culture and the content of socialist core values. The connotation of red culture is very rich. It inherits the excellent traditional culture idea of China and innovates in the continuous practice of Chinese revolution and construction. Its cultural heritage function is a bridge connecting Chinese history and contemporary reality [3]. In addition, when carrying out the relevant research on the integration of red culture into the socialist core values, we need to pay attention to the connection between the red culture and the specific level of the socialist core values, deepen the internal consistency of the different contents of the red culture and the socialist core values at different levels of the country, society and individuals, and only find the agreement of the two contents from three levels first It can better find the starting point of education in the education of socialist core values of college students.

$\mathrm{Xi}$ Jinping stressed at the National Conference on Ideological and political work in colleges and universities: we should make good use of the main channel of classroom teaching. We should persist in improving the ideological and political theory course, enhance the affinity and pertinence of Ideological and political education, and meet the needs and expectations of students' growth and development. All other courses should observe a certain section of the canal and form a good responsibility field, so that all kinds of courses can be aligned with ideological and political theory courses [4]. Red culture is born with vivid and vivid characteristics. Integrating red culture into the education of socialist core values of Ideological and political theory courses in colleges and universities can further stimulate the vitality of the classroom and enhance the enthusiasm of students. Therefore, we should make good use of the main channel of Ideological and political theory courses to infuse red culture into the education process of socialist core values and optimize the teaching process. The teaching content of the course is particularly important.

\subsection{Forming a Joint Force: Building an All-Round Red Culture Education System for the Whole Staff}

Synergy is the fundamental feature of red culture in the education of socialist core values in colleges and universities, and also the fundamental guarantee of 
red culture in the education of socialist core values in colleges and universities. Only in the process of education, we can ensure that all elements, all links and all measures work together and develop together, can we achieve the effect of $1+$ $1>2$. The government and the school are the two main bodies of the education of red culture integrated into the socialist core values. Most of the red culture resources are planned and managed by the government. If the university wants to use the red resources for research and teaching, it must fully cooperate with the government to integrate the resources and establish a deep community of theoretical and practical education. It can be seen that the government, society and schools should form consistent goals and ideas, attach great importance to the integration of red culture into the education of socialist core concept in colleges and universities as the responsibility of the whole society, and form a joint force in policy measures and promotion mechanism, with clear division of labor and mutual matching.

The outline for the implementation of the project of improving the quality of Ideological and political work in colleges and universities indicates that the ideological and political education should "comprehensively plan all fields of running schools and running schools, realize the cooperation, peer-to-peer and interconnection of various education work [5]." As the main body of red culture integrated into the education of socialist core values, the coordination among various departments and colleges within the university is also very important. The integration of red culture into colleges and universities will inevitably require the joint efforts and cooperation of the student work department, financial department, logistics department, etc. so as to cultivate the soil suitable for the rooting and germination of red culture in colleges and universities. School of Marxism should also take the responsibility of integrating red culture into the construction of Ideological and political theory course in colleges and universities, actively explore new educational ideas in theory and practice, enhance the enthusiasm and participation of schools, colleges and students, and promote the development of the course. In addition, managers, teachers, counselors and so on should earnestly perform their educational responsibilities, integrate the promotion of socialist core values into the actual work, pass on the red spirit through words and deeds, and guide the formation of students' values.

\section{Concluding Remarks}

Chinese red culture is a dynamic development, rich and perfect process. No matter the vivid heroic stories or the revolutionary sites, they are influencing the thoughts and values of college students imperceptibly. Colleges and universities should fully tap the local rich red education resources, enrich the content, and constantly innovate the education form. Cultivate college students to develop the quality of hard work, inherit the excellent revolutionary tradition and red gene, guide college students to firmly establish the socialist core values, further highlight the school characteristics, and improve the quality of talents. 


\section{Conflicts of Interest}

The author declares no conflicts of interest regarding the publication of this paper.

\section{References}

[1] Liu, J.W. (2018) Research on the Integration of Red Culture into the Education of Socialist Core Values in Colleges and Universities. People's Publishing House, Beijing.

[2] Chen, S.P. and Zheng, Z.B. (2015) Investigation on the Current Situation and Path of Socialist Core Values Education of College Students-Taking Some Colleges and Universities in Fuzhou as an Example. Research on Ideological Education, No. 11, 81-84.

[3] Ma, S. (2019) A Comparative Study on Cultural Innovation of Red Culture Integrated into Socialist Core Values. Education in Colleges and Universities, No. 30, 12-13.

[4] Liu, J.T. and Zhao, G. (2016) Running Ideological and Political Work through the Whole Process of Education and Teaching, Creating a New Situation for the Development of Higher Education in China. People's Daily, 2016-12-09.

[5] Ministry of Education of the Communist Party of China (2017) Implementation Outline of Ideological and Political Work Quality Improvement Project in Colleges and Universities. Guangming Daily, 2017-12-07. 